\title{
Erik Petrovski
}

\section{De stabile frivillige}

\section{Betydningen af kapitalressourcer, livsfaser og organisatorisk kontekst for vedvarende frivilligt arbejde}

Jeg fremsætter hypotesen, at stabilt frivilligt arbejde over længere tidsperioder afhænger af de kapitalressourcer der medbringes til arbejdet, den livsfase arbejdet foregår i, samt den organisatoriske kontekst arbejdet udføres inden for. Hypotesen testes ved hjælp af paneldata fra befolkningsundersøgelsen af frivilligt arbejde '04 og '12. Jeg konkluderer, at selvom enkelte kapitalressourcer og livsfaser har en indflydelse, så er det de organisatoriske forhold, blandt andet medlemskab og arbejdsintensitet, der har den mest entydige indvirkning.

Søgeord: frivilligt arbejde, paneldata, integreret teori, frivillighedsdynamik, medlemskab. 
$\mathrm{D}$ enne artikel vil bidrage til at tegne en tydeligere profil af de frivillige. Det empiriske fokus er dog ikke - som i størstedelen af undersøgelserne på området - at kortlægge, hvem der bliver frivillige. I stedet vil jeg bidrage til den mere sparsomme forståelse af, hvilke frivillige der vælger at fortsætte deres frivillige arbejde over en længere tidsperiode (Wilson 2012). I forlængelse heraf vil jeg afgøre, hvorvidt fastholdelse i frivilligt arbejde blot bør forstås som et spørgsmål om social selektion, eller hvorvidt organisatoriske aspekter i tilknytning til det frivillige arbejde er i stand til at fastholde de frivillige på tværs af sociale skel.

Vi ved fra et væld af både dansk og international forskning, at det største antal frivillige skal findes inden for befolkningsgrupper med høje grader af social, kulturel og human kapital - samt gerne midt i livet, hvor børn og andre sociale forpligtelser bringer den enkelte i kontakt med muligheder for at arbejde som frivillig (f.eks. Fridberg, Henriksen et al. 2014; Musick 2007; Svedberg, Essen \& Jegermalm 2010; Wilson 2000; Wollebæk \& Sivesind 2014). Det skyldes især, at ressourcestærke individer er mere eftertragtede for frivillige organisationer og samtidig lettere mestrer de frivillige arbejdsopgaver, de stilles over for. Det kan derfor også med god grund formodes, at disse ressourcestærke befolkningsgrupper ikke blot har nemmere ved at påbegynde frivilligt arbejde, men også har lettere ved at fortsætte i det frivillige arbejde. Den hypotese har sit teoretiske udgangspunkt i den integrerede teori om frivilligt arbejde og i livsfaseteori (Wilson \& Musick 1999).

I artiklen vil jeg dog argumentere for, at rent individfokuserede aspekter som livsfaser og kapitalressourcer er utilstrækkelige til fuldt ud at forstå stabilt frivilligt arbejde. Især må betydningen af den organisatoriske kontekst ikke overses, som meget af frivillighedsforskningen desværre har en tendens til at gøre (ifølge Haski-Leventhal \& Bargal 2008; Moreno-Jiménez \& Villodres 2010; Penner 2002). Derfor udvider jeg mit empiriske fokus til også at se på, om organisatoriske aspekter i tilknytning til det frivillige arbejde er i stand til at fastholde de frivillige på tværs af forskelle i deres kapitalressourcer. Begrundelsen herfor er, at når individer gennem deres frivillige arbejde påtager sig roller i frivillige organisationer, indgår de i bindende organisatoriske strukturer, der fostrer en forpligtelse og et tilhørsforhold, som går på tværs af ressourceskel og dermed fastholder den enkelte i rollen som frivillig (Hustinx 2010a; Tang et al. 2014; Wilson \& Musick 1999). Den integrerede teori udvides dermed med en forståelse af organisatoriske forhold ved det frivillige arbejde såsom arbejdsområder, arbejdstid og medlemskab.

Min empiriske basis er paneldata fra den danske befolkningsundersøgelse af frivilligt arbejde, der blev udført i 2004 og 2012.

Konklusionen er overordnet set, at så snart den enkelte først ér blevet frivillig, er det ikke entydigt et spørgsmål om kapitalressourcer, men i høj grad også et spørgsmål om arbejdets natur og omfang, der afgør, hvorvidt frivilligt arbejde bliver et kort bekendtskab eller et vedvarende engagement. Konklu- 


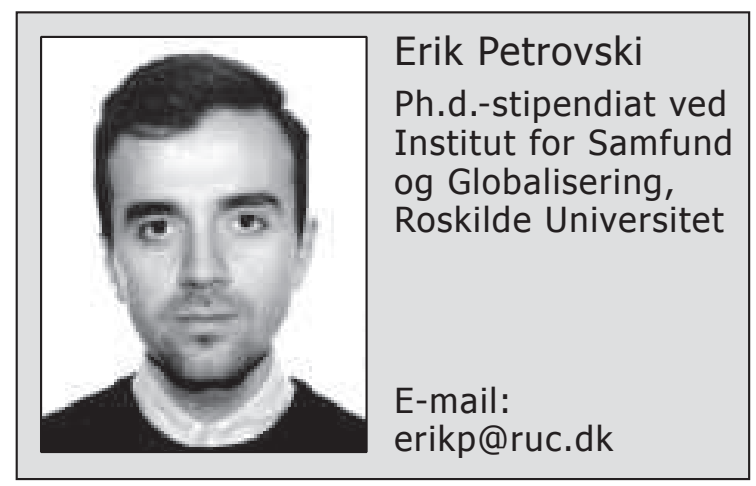

sionen baserer sig blandt andet på, at undersøgelsen viser, at centrale mål for human kapital såsom uddannelse og beskæftigelse ikke har nogen signifikant positiv betydning, samt at social kapital kun viser sig at have en svag positiv effekt. Disse mål er ellers blandt de klareste indikatorer på at påbegynde frivilligt arbejde. Modsat er det slående, at samtlige mål for den organisatoriske kontekst har en stærk og signifikant indvirkning.

Det er en konklusion med vigtige perspektiver i en tid, hvor den organisatoriske kontekst for det frivillige arbejde er under stærk forandring hen mod det ikke-medlemsbaserede og mindre arbejdsintensive engagement. Men netop medlemskab og høj arbejdsintensitet viser sig i undersøgelsen her at være en klar indikator på stabilt frivilligt arbejde.

\section{Adgang til frivilligt arbejde}

Frivilligt arbejde defineres som en særlig form for ulønnet arbejdsindsats, der ikke udføres af tvang, som for eksempel det betalte arbejde, der er baseret på kontraktuelle forpligtelser, gør. Det frivillige arbejde udføres derimod af egen fri vilje og lyst. Samtidig er det frivillige arbejde til gavn for personer uden for den umiddelbare familie og venskabskreds, hvilket adskiller det fra den rene familiære eller venskabelige tjeneste (Fridberg, Henriksen et al. 2014). Eksempler på frivilligt arbejde er mange og omfatter blandt andet spejderledere, lektiehjælpere, naturguider, fodboldtrænere og meget andet.

Men selvom frivilligt arbejde altså adskiller sig substantielt fra betalt arbejde, så har frivilligt og betalt arbejde et centralt lighedspunkt: De involverer begge produktionen af et gode for andres konsumption - tænk blot på børns idræt, lektiehjælp og spejderture (Taylor 2004). Som følge heraf bruger deltagelsen i frivilligt arbejde ressourcer som energi og tid og kræver bestemte færdigheder, som nogle mennesker i højere grad besidder end andre (Musick 2007). Derfor er det i forskningssammenhænge nyttigt at se frivilligt arbejde i samme lys som det betalte arbejde. Det tillader os nemlig at fokusere på hvilke ressourcer, der kræves for at tage del i produktionen af de goder, den frivillige sektor leverer (Wilson \& Musick 1997). Netop den tilgang har vist sig at være særlig frugtbar i adskillige empiriske studier (f.eks. Fridberg, Henriksen et al. 2014; Musick 2007; Svedberg et al. 2010; Wilson 2000; Wollebæk \& Sivesind 2014). 
Med udgangspunkt i den erkendelse er den integrerede teori om frivilligt arbejde særligt godt egnet som teoretisk ramme, da teorien søger at forklare deltagelse i frivilligt arbejde på baggrund af tre betragtninger: For det første, at frivilligt arbejde er en produktiv aktivitet og derfor kræver human kapital (uddannelse og beskæftigelseserfaring); for det andet, at det udføres kollektivt og derfor kræver social kapital (sociale netværk); og for det tredje, at det styres af etik og derfor kræver kulturel kapital (samfundsorientering). Grundtanken bag teoriens kapital-tankegang er, at når personer stilles over for transaktionsomkostningerne ved at engagere sig i frivilligt arbejde, vil de med en overflod af sociale, humane og kulturelle ressourcer i højere grad have mulighed for at vælge at engagere sig frivilligt (Wilson \& Musick 1997).

I det følgende afsnit skaber jeg forbindelsen mellem, hvorfor de ressourcer, der kræves for at individer påtager sig frivilligt arbejde, også kan forventes at have en betydning for at fortsætte dette arbejde. Det sker med udgangspunkt i de tre former for kapital.

\section{Kapitalressourcer}

Human kapital er den række af individuelle ressourcer, der gør produktive aktiviteter mulige. Hertil tæller for eksempel aktuel erhvervserfaring, uddannelse, godt helbred, og andet der gør det nemmere for enkeltpersoner at mestre de arbejdsopgaver, de stilles over for (Coleman 1988). Derfor får både højtuddannede og erhvervsbeskæftigede - der kan overføre aktuel viden, færdigheder og certificeringer fra deres uddannelse og betalte beskæftigelse til det frivillige arbejde - lettere adgang til de frivillige arbejdsopgaver, de ønsker at beskæftige sig med (Smith 1994; Wilson 2000).

Derudover er fleksibel fri tid til at udføre det frivillige arbejde ligeledes en vigtig human kapitalressource. Langt de fleste frivillige vil nemlig ikke have mulighed for at komme og gå som de lyster. I stedet forpligter man sig som frivillig oftest til en bestemt tidsplan, der skal koordineres med andre frivillige. Den betragtning har konsekvenser for betydningen af erhvervsbeskæftigelse, som ligeledes er en produktiv aktivitet, der forbruger individers frie tid. Det kan derfor forventes, at individer med fleksible frem for ufleksible arbejdstider i højere grad har muligheden for selv at planlægge deres arbejdsliv således, at de kan prioritere det frivillige arbejde (Tang et al. 2014; Wilson \& Musick 1999). Det betyder konkret, at fleksibelt frem for ufleksibelt erhvervsarbejde i højere grad må betragtes som en human kapitalressource for frivilligt arbejde.

Eftersom frivilligt arbejde er selvvalgt og ikke økonomisk eller på anden måde en nødvendig produktiv aktivitet for den enkelte, vil jeg fremlægge hypotesen, at individer med lave humane kapitalressourcer i højere grad vil vælge at opgive deres frivillige arbejde, formentlig for at prioritere deres begrænsede ressourcer til fordel for den mere nødvendige indsats i hjemmet eller på arbejdsmarkedet (Tang et al. 2014; Tang et al. 2010; Wilson \& Musick 1999). 
Social kapital defineres i denne sammenhæng snævert som de sociale netværk, der gør det nemmere for individer at indgå i samarbejde med andre (Coleman 1988). Eftersom frivilligt arbejde er en kollektiv aktivitet, der kræver evner for at indgå i et koordineret samarbejde med et væld af forskelligartede personer, er det rimeligt at antage, at personer med veludbyggede sociale netværk i højere grad vil føle sig hjemme i disse sociale fællesskaber og derfor forblive i det frivillige arbejde (Wilson \& Musick 1999). Sociale netværk er desuden informationsbærende, og derfor er det gennem sociale netværk, at langt størstedelen af de frivillige har adgang til information om muligheder for at yde en frivillig indsats (Granovetter 1973). Derfor er det også oplagt at antage, at det er gennem sociale netværk, at individer kontinuerligt vil få muligheder for at deltage i frivilligt arbejde (Wilson \& Musick 1999). Hypotesen bliver således, at individer med høje grader af social kapital i højere grad vælger at fortsætte som frivillige.

Kulturel kapital består af individuelle smage og tilbøjeligheder, der for eksempel kan erhverves gennem en bestemt opvækst inden for familien. Antagelsen er, at for individer der er socialiseret inden for en frivillighedskultur, vil frivilligt arbejde i højere grad blive set i et positivt lys eller ligefrem som noget naturgiven. Disse individer vil også i højere grad vide, hvordan man bedst kommer ind i det frivillige arbejde. Så ligesom man kan udvikle en smag for fine vine, kan bestemte grupper udvikle en smag for frivilligt arbejde. Kultur opfattes altså her ikke som en smag efter bestemte kulturelle objekter, men som en smag for bestemte sociale praksisser såsom frivilligt arbejde (Wilson \& Musick 1997). Hypotesen er, at individer med høje grader af kulturel kapital føler sig bedre hjemme i det frivillige arbejde og derfor vælger at vedblive som frivillige.

\section{Livsfaser}

Ikke bare kapitalressourcer, men også livsfaser har vist sig at have en tæt relation til deltagelse i frivilligt arbejde (Wilson 2012). Livsfasekonceptet refererer til, hvordan sociale institutioner som familie, skole og arbejde indvæves i og dermed former individers liv. Som sådan er selve aldersvariablen af mindre interesse som selvstændigt mål, men refererer i stedet til det stadie i livet, en person er nået (Musick 2007). Frivillighedsforskningen opdeler individers liv i tre stadier: ungdom, voksenliv og alderdom. Især den tidlige ungdom er karakteriseret ved forbrug af frivilligt arbejde i relation til fritidsaktiviteter, men med lidt eller ingen engagement $i$ arbejdet selv. Den senere ungdom er karakteriseret ved mindre engagement i frivillighed til fordel for uddannelse. Det er først i voksenlivet, at især det faktum at børn engagerer sig i skole og fritidsaktiviteter medvirker til, at forældre bliver draget med ind som bestyrelsesmedlemmer, fodboldtrænere og lignende. Men også indgangen til arbejdsmarkedet med dertilhørende opbygning af human kapital er af stor vigtighed (Musick 2007). De stabile mønstre af frivilligt arbejde, der især kan 
forventes i voksenlivet, skyldes desuden den særlige stabilitet af de førnævnte roller på jobbet, i ægteskabet og som forældre i denne periode. Den stabilitet kan forventes at give ekstra overskud til deltagelse i ikke-essentielle produktive aktiviteter uden for hjemmet såsom frivilligt arbejde (Flanagan \& Levine 2010; Wilson 2012). Alderdommen er derimod karakteriseret ved et exit fra samtlige af de førnævnte roller samt et nedadgående helbred. Derfor kan det forventes, at denne livsfase kan medføre, at også det frivillige arbejde afvikles (Musick 2007).

\section{Organisatorisk kontekst}

Frivilligt arbejde foregår - ligesom betalt arbejde - altid i en organisatorisk kontekst. Det kan for eksempel være en idrætsklub, en lektiecafé eller et plejehjem. Og ligesom med betalt arbejde, så kan den kontekst, den frivillige vælger at udføre sit arbejde inden for, antages at have betydning for både lysten og følelsen af forpligtelse til at føre arbejdet videre. Jeg har valgt at fokusere på især to parametre, som jeg vil argumentere for kan være særligt afgørende i den henseende: arbejdsintensitet og medlemskab.

Når man engagerer sig som frivillig, påtager man sig samtidig en rolle i en organisation, der i varierende grad vil være afhængig af ens frivillige arbejdskraft (Wuthnow 1995). I modsætning til private arbejdspladser, så er de organisationer, som frivillige finder deres virke i, dog i langt højere grad karakteriserede ved ikke at have fastlagte forventninger til arbejdsintensitet. Som frivillig har man derfor i højere grad mulighed for selvbestemmelse i relation til, hvor omfattende ens rolle bør være (Haski-Leventhal \& Bargal 2008; Meyer et al. 2002). Der kan naturligvis være flere motiver til at vælge at forøge sin arbejdsintensitet, såsom tilfredsstillelsen der udledes fra arbejdet eller signalværdien udadtil - for at nævne et par eksempler (Qvist 2014). Men holdes fokus på det organisatoriske perspektiv, så kan den frivilliges valg om at udøve en større mængde arbejde for en given frivillig organisation forstås som en beslutning om at forøge sin tidsmæssige investering i, at den enkelte organisation kan fungere og nå sine målsætninger. Det er grundlæggende set et valg, der hænger sammen med en positiv identifikation med og anerkendelse af vigtigheden af organisationen og dens arbejde (Cuskelly \& Boag 2001; Meyer et al. 2002). Dermed forøges incitamentet for at fortsætte for de særligt engagerede frivillige med en højere arbejdsintensitet, da disse i større udstrækning har investeret deres tid og arbejdskraft i organisationens videreførelse og succes samt i opnåelsen af de bredere målsætninger, organisationen arbejder hen mod (Cuskelly \& Boag 2001; Wilson \& Musick 1999). I praksis betyder det, at en frivillig, der investerer seks timer hver uge for at være træner i den lokale fodboldklub, vil have tendens til at tillægge klubbens resultat til både dette og næste års pokalturnering en højere værdi og derfor have sværere ved at opgive sit arbejde end en lignende frivillig, der lægger bare et par timer hver anden uge. Derfor er min hypotese, at jo mere tid den 
enkelte vælger at dedikere til frivilligt arbejde, jo mere sandsynligt er det, at vedkommende forbliver frivillig.

Ud over arbejdsintensitet, så kan medlemskabet også være af særlig betydning. I sin klassiske form betyder medlemskabet, at den enkelte frivillige er udstyret med en række formaliserede og demokratisk funderede rettigheder, som ultimativt sikrer deltagernes medejerskab og indflydelse i den forening, som arbejdet udføres for. Således har den medlemsfrivillige møde- og stemmeret til generalforsamlingen og kan vælges ind i foreningens ledende organer (Ibsen et al. 2013; Selle 2013; Wollebæk \& Sivesind 2014). Den frivillige, som ikke er medlem, har derimod ikke automatisk samme demokratisk funderede indflydelsesmuligheder, men er oftere begrænset til at yde en frivillig indsats på præmisser, som lønnede ansatte har fastlagt - om end måske i en mindre formaliseret dialog med de frivillige (Koch-Nielsen \& Michaelsen 2003). De ikke-medlemsbaserede former for frivillighed findes primært inden for frivillige organisationer samt offentlige eller selvejende institutioner. Det kan dreje sig om frivillige i kommunale besøgsordninger, i aktivitetscentre eller frivillige i de store humanitære NGO'er. Den medlemsbaserede frivillighed findes typisk inden for foreningerne, og eksempler kan være trænerne i den lokale fodboldklub, spejderledere eller naturguider i naturfredningsforeninger (Henriksen 2014a).

Forskere har længe påpeget, at på grund af den ikke-medlemsbaserede frivilligheds manglende demokratiske fundering, så har den enkelte frivillige ikke i samme omfang mulighed for at blive inddraget i det organisatoriske arbejde og vil dermed ikke i samme grad være integreret i beslutningsstrukturerne inden for organisationen. Således bliver den enkeltes motivation til at fortsætte som frivillig i højere grad fokuseret på værdien af arbejdet i sig selv og i mindre grad på organisationen, som arbejdet udføres for. Den ikkemedlemsbaserede frivillige kan derfor antages at have lettere ved at forlade den pågældende organisation - og således også det frivillige arbejde som sådan - i modsætning til den medlemsfrivillige, der forventes at være engageret i en mere ansvarsfuld og forpligtende rolle i forhold til foreningens fremtidige udvikling og målsætninger (Henriksen 2014a; Wollebæk \& Sivesind 2014).

Det er samtidig målsætninger, som han eller hun kan have været med til at vedtage eller ligefrem udforme. I de tilfælde kan der yderlige være tale om, at medlemskabet sikrer en overensstemmelse mellem mål og værdier hos den enkelte frivillige og så organisationen, den frivillige arbejder for (Cuskelly \& Boag 2001; Henriksen 2014a). Anderledes ser det ud med den ikke-medlemsbaserede frivillige, der generelt har færre muligheder for at præge organisationens generelle udvikling eller præmisserne for sit eget arbejde. Uden disse betydelige formelle indflydelsesmuligheder, der kan sikre den enkelte frivillige en stemme inden for organisationen, kan den eneste handlemulighed i tilfælde af et misforhold mellem den generelle udvikling for organisationen og den enkelte frivilliges prioriteringer være at forlade den enkelte organisation 
og dermed måske også det frivillige arbejde som sådan (Allen \& Mueller 2013; Elstub 2010; Garner \& Garner 2011; Wollebæk \& Sivesind 2014).

Fordi medlemskabet både sikrer den frivillige indflydelsesmuligheder samt et ansvar for foreningens udvikling, er min hypotese, at medlemsfrivillige i højere grad forbliver frivillige.

Et tredje element fra den organisatoriske kontekst, der er værd at inddrage i denne analyse, er de forskelle, som findes på organisationer, der placeres inden for forskellige arbejdsområder. Især de religiøse frivillighedsbaserede fællesskaber har vist sig at have en afgørende positiv betydning for vedvarende frivilligt arbejde (Wilson \& Janoski 1995; Wilson \& Musick 1999). Forklaringen kan findes $i$, at den religiøse frivillighed - i endnu højere grad end andre former for frivillighed - tilbyder den enkelte et vedvarende og særligt tæt knyttet værdifællesskab, hvorfra han eller hun udleder kerneelementer af sin identitet, verdenssyn og eksistensgrundlag (Wuthnow 1995, Taniguchi \& Thomas 2010). Dette stærke gruppetilhørsforhold kommer altså blandt andet til udtryk gennem øget stabilitet i det frivillige arbejde (Wilson \& Musick 1999).

Derfor er min hypotese, at frivillige inden for det religiøse område i særlig høj grad forbliver i det frivillige arbejde.

\section{Data og metode}

Data består af et panel på 1.981 personer (n=1.981). Paneldeltagerne er en undergruppe bestående af de $63 \%$ fra den repræsentative befolkningsundersøgelse af frivilligt arbejde i $2004\left(\mathrm{n}_{2004}=3.134\right.$ \& svarprocent=75), som valgte at gennemføre endnu et interview i $2012(\mathrm{t}=2)$. Undersøgelsen baserer sig på telefoninterviews og er gennemført i et samarbejde mellem RUC, SDU, SFI og AAU. ${ }^{1}$ Udvælgelseskriterierne er personer, der i 2004 var mellem 16 og 85 år og havde fast bopæl i Danmark.

Som ved lignede undersøgelser, er paneldeltagerne også i dette tilfælde selvselekteret på baggrund af især ressourcestærkhed og interesse for emnet (se Hermansen 2015). Mål i panelet for totalantal stabilt frivillige, beskæftigede, akademikere med videre er derfor ikke nødvendigvis repræsentative for befolkningen som helhed. Men de mekanismer, der identificeres i panelet - altså sammenhængen mellem de enkelte mål - bør med stor sikkerhed fortsat være gyldige, og derfor kan brugen af paneldata legitimeres (Frederiksen \& Møberg 2014).

\section{Afhængig variabel}

Stabilt frivilligt arbejde ('04 $\mathcal{E}$ '12): I begge undersøgelser blev respondenter spurgt, om de havde udført frivilligt arbejde inden for det seneste år på tolv forskellige arbejdsområder. Variablen kodes som en dummyvariabel, der antager værdien 1 hvis respondenten var frivillig på mindst ét område i både '04 og '12, og 0 hvis respondenten kun var frivillig i '04 men ikke'12. 
Variablen er det bedste mål for stabilt frivilligt arbejde, der er til rådighed, men har alligevel visse begrænsninger. For det første er det ikke muligt at tage højde for, om den enkelte skulle have skiftet over til en ny organisation i

mellemtiden. ${ }^{2}$ For det andet vil der, på grund af det store tidsmæssige spring på otte år mellem undersøgelsens to bølger, findes en risiko for, at enkelte respondenter kan have været ude af det frivillige arbejde i mellemtiden og derfor ikke kan betragtes som stabilt frivillige. Alt andet lige må det dog antages, at respondenter, der er frivillige på begge tidspunkter, med størst sandsynlighed er de stabilt frivillige eller i det mindste har den tætteste tilknytning til det frivillige arbejde.

\section{Human kapital}

Uddannelse ('12): Det højest opnåede uddannelsesniveau bruges som mål for respondenters uddannelse. Uddannelse er kodet som en dummy-variable, der angiver, om respondenten har en lang videregående uddannelse eller ej. ${ }^{3}$

Helbred $\mathcal{E}$ fysisk mobilitet ('12): Det aktuelle psykiske og fysiske helbredsog funktionsniveau måles på en selvrapporteret ordinal fempunktsskala. Spørgsmålet er kun stillet i 2012.

Beskæftigelse ('12): Der anvendes en serie af dummyvariable. Fleksibelt arbejde angiver om respondenten har angivet arbejde med fleksible arbejdstider. Ufleksibelt arbejde angiver om respondenten har angivet arbejde med ufleksible arbejdstider. Studerende angiver om respondenten er fuldtidsstuderende. Referencekategorierne er pensionister og arbejdsløse, som er valgt, fordi disse to grupper ikke er aktuelt beskæftiget i andre produktive aktiviteter.

\section{Social kapital}

Sociale netværk ('12): Der er konstrueret et indeks bestående af fire variable, som på fempunkts ordinale skalaer måler graden af kontakt til (1) familie og slægt, (2) naboer og andre i nærområdet, (3) tidligere kollegaer samt (4) nuværende kollegaer. ${ }^{4}$

\section{Kulturel kapital}

Tradition for frivilligt arbejde ('12): Respondenter er blevet spurgt, om de under opvæksten mener, at der har været tradition for frivilligt arbejde $i$ familien. Svarene falder på en fempunkts ordinal skala.

\section{Livsfaser}

Alder ('12): Alder inddrages med seks tiårskategorier fra 24 år og op. Kategorien 24-33 år svarer til sen ungdom, kategorierne mellem 34-63 år til voksenlivet og 64+ til alderdom.

Børn i skolealderen ('12): Hjemmeboende børn i skolealderen defineres som børn i alderen (6-15 år) i 2012. ${ }^{5}$ 


\section{Organisatorisk kontekst}

Medlemskab ('04): Respondenter er blevet spurgt, om de er medlemmer af den organisation, det frivillige arbejde udføres for. Svarer respondenten ja mindst én gang, kodes vedkommende som medlemsfrivillig. ${ }^{6}$

Logaritmen af frivilligt timetal ('04): Respondenter har desuden estimeret deres årlige timeforbrug på frivilligt arbejde. For at mindske betydningen af ekstremt høje timetal (outliers), er logaritmen af timetallet anvendt. For at bevare stikprøvestørrelsen er enkelte manglende besvarelser erstattet med gennemsnitsværdien. ${ }^{7}$

Religionsområdet ('04): Respondenter der har arbejdet som frivillige inden for religionsområdet.

For at kunne sammenligne stabilt frivillige med frafaldne, er målene for den organisatoriske kontekst alle hentet fra 2004-undersøgelsen. Den enkelte frivillige kan dog have ændret status i mellemtiden - for eksempel kan man have justeret sit tidsforbrug væsentligt på otte år - og det vil påvirke reliabiliteten af disse mål. Det lader dog til, at den organisatoriske kontekst er relativt stabil over tid. Tidforbruget i ' 04 er således stærkt signifikant korreleret med tidsforbruget i ' $12\left(\mathrm{r}=0,27^{* * *}\right), 80 \%$ af de stabile medlemsfrivillige er medlemmer begge år og $60 \%$ af de stabile religionsfrivillige er forblevet på religionsområdet.

\section{Kontrolvariable}

Køn ('12): Mænd arbejder i højere grad frivilligt (Fridberg et al. 2014). For at undersøge, om det også har effekt på stabiliteten, inkluderes køn.

Logaritmen af antal år boet i lokalområdet ('12): Personer, der bor mange år i samme lokalområde, kan have større viden om lokale frivillige aktiviteter og have større sociale netværk i lokalområdet. Igen er logaritmen anvendt for at håndtere ekstreme værdier, og de få manglende besvarelser er erstattet med gennemsnitsværdien.

\section{Deskriptiv analyse}

Panelet kan deles op i fire grupper med hensyn til, hvorvidt den enkelte yder en frivillig indsats: (1) de stabilt ikke-frivillige, som ikke har udøvet frivilligt arbejde i hverken 2004 eller 2012, (2) de stabilt frivillige, som har udøvet frivilligt arbejde i både 2004 og 2012, (3) de frafaldne, som har udøvet frivilligt arbejde i 2004 men ikke 2012, og til sidst (4) de nytilkomne, som ikke har udøvet frivilligt arbejde i 2004 men kun i 2012. Den simple fordeling i panelet for de fire grupper ses i tabel 1.

Den primære interesse for undersøgelsen er forskellen i kapitalressourcer, livsfaser og organisatorisk kontekst for gruppen af stabilt frivillige (de $23 \%$ ) over for de frafaldne (de $16 \%$ ). For at give en forståelse af den sociale profil for de to grupper, vil jeg dog først sammenligne dem med de stabilt ikkefrivillige (de $47 \%$ ). Det er gjort i nedenstående tabel, hvor de tre grupper er opdelt på baggrund af relevante variable. 
Tabel 1.

Andele af frivillige inden for det sidste år i 2004 og 2012 blandt paneldeltagere.

\begin{tabular}{lrrr}
\hline & Ikke-frivillig '12 & Frivillig '12 & Total \\
\hline & & & \\
Ikke-frivillig '04 & 931 & 284 & 1.215 \\
& $47 \%$ & $14 \%$ & $61 \%$ \\
Frivillig '04 & & & \\
& 315 & 450 & 765 \\
& $16 \%$ & $23 \%$ & $39 \%$ \\
Total & & & \\
& 1.246 & 734 & 1.980 \\
& $63 \%$ & $37 \%$ & $100 \%$ \\
\hline
\end{tabular}

Som det fremgår af tabel 2, adskiller de stabilt ikke-frivillige sig entydigt fra både stabilt frivillige og de frafaldne på stort set alle parametre. ${ }^{8}$ Stabilt ikkefrivillige har mindre fleksibelt arbejde, lavere uddannelse, dårligere helbred, færre sociale netværk, er i mindre grad vokset op med en tradition for frivillighed og har ikke børn i skolealderen. ${ }^{9}$ Den konklusion støtter klart den integrerede teori om frivilligt arbejde: Deltagelse i frivilligt arbejde, selv kortvarigt, afhænger i høj grad af kapitalressourcer og livsfaser.

For undersøgelsens fokus på forskelle i kapitalressourcer mellem stabilt frivillige og frafaldne betyder det, at eftersom lavressource-personer ikke i samme omfang påbegynder frivilligt arbejde, så bliver det noget sværere at observere klare forskelle i kapitalressourcer mellem dem, som forlader det frivillige arbejde igen, og så dem som bliver: De to grupper er begge karakteriseret ved et relativt højt ressourceniveau. Alligevel er der dog en række centrale ressource- og livsfasemål, som er signifikant forskellige mellem de stabile og de frafaldne, og det giver god basis for at fortsætte med ressourceperspektivet i den følgende multivariate analyse. Samtidig er det interessant at observere, at samtlige mål for organisatorisk kontekst har en stærk signifikant bivariat betydning.

\section{Multivariat analyse og diskussion}

Til den multivariate analyse anvender jeg en stationær logistisk regressionsmodel. Modellen udtrykker den simultane sandsynlighed for at være frivillig i både 2004 og 2012 frem for kun i 2004 og ikke i 2012, givet en række individuelle kvaliteter. De estimerede $\beta$-koefficienter, der er rapporteret $\mathrm{i}$ tabel 3 , er de logistiske koefficienter, hvorfra odds-ratio koefficienterne ved $x=1$ er udledt ved hjælp af eksponentialfunktionen (). Odds-ratio-koefficienter over ét $(\mathrm{OR}>1)$ angiver en positiv sandsynlighed for stabil frivillighed, mens koefficienter under ét $(\mathrm{OR}<1)$ angiver en negativ sandsynlighed. 
Tabel 2.

Deskriptiv statistik over de tre befolkningsgrupper i panelet, samt t-test af andelsforskelle mellem stabilt frivillige og frafaldne ( $\alpha=10 \%)(* p<0,10 * * p<0,05 * * * p<0,01)$. $\left(n_{1}=931\right),\left(n_{2}=450\right),\left(n_{3}=315\right)$.

\begin{tabular}{|c|c|c|c|c|}
\hline & $\begin{array}{c}\begin{array}{c}\text { Stabilt ikke- } \\
\text { frivillige } \\
\mu 1\end{array} \\
\end{array}$ & $\begin{array}{c}\begin{array}{c}\text { Stabilt } \\
\text { frivillige } \\
\mu 2\end{array} \\
\end{array}$ & $\begin{array}{c}\text { Frafaldne } \\
\mu_{3}\end{array}$ & $\begin{array}{c}\text { Difference } \\
\mu 2-\mu 3\end{array}$ \\
\hline \multicolumn{5}{|l|}{ Kapitalressourcer } \\
\hline Fleksibelt lønarbejde (o-1) & 0,15 & 0,27 & 0,23 & 0,04 \\
\hline Ufleksibelt lønarbejde (o-1) & 0,40 & 0,40 & 0,45 & $-0,05$ \\
\hline Studerende (o-1) & 0,04 & 0,03 & 0,04 & $-0,01$ \\
\hline LVU (o-1) & 0,10 & 0,19 & 0,14 & $0,05^{* *}$ \\
\hline Helbred \& fysisk mobilitet (o-2) & 1,64 & 1,79 & 1,68 & $0,10^{* * * *}$ \\
\hline Sociale netværk (o-4) & 2,31 & 2,56 & 2,47 & $0,09^{* *}$ \\
\hline Tradition for frivillighed (o-3) & 0,68 & 1,31 & 0,94 & $0,37^{* * *}$ \\
\hline \multicolumn{5}{|l|}{ Livsfaser } \\
\hline $24-33(0-1)$ & 0,14 & 0,08 & 0,12 & $-0,04^{*}$ \\
\hline $34-43(0-1)$ & 0,18 & 0,22 & 0,16 & $0,07^{* *}$ \\
\hline $44-53(0-1)$ & 0,19 & 0,23 & 0,31 & $-0,08^{* *}$ \\
\hline $54-63(0-1)$ & 0,21 & 0,24 & 0,21 & 0,02 \\
\hline $64-73(0-1)$ & 0,18 & 0,14 & 0,12 & 0,02 \\
\hline $74+(0-1)$ & 0,10 & 0,09 & 0,07 & 0,02 \\
\hline Børn i skolealder (o-1) & 0,17 & 0,25 & 0,20 & 0,05 \\
\hline \multicolumn{5}{|l|}{ Organisatorisk kontekst } \\
\hline Religionsområdet (o-1) & - & 0,08 & 0,03 & $0,05^{* * *}$ \\
\hline Medlemskab (o-1) & - & 0,85 & 0,74 & $0,11^{* * *}$ \\
\hline Log årlige frivillige timer & - & 4,17 & 3,85 & $0,32^{* * *}$ \\
\hline \multicolumn{5}{|l|}{ Kontrolvariable } \\
\hline Mand (o-1) & 0,43 & 0,54 & 0,48 & 0,06 \\
\hline Log år boet i lokalområde & 2,57 & 2,71 & 2,50 & $0,21^{* * *}$ \\
\hline
\end{tabular}

I den logistiske regressionsmodel, som ses i tabel 3, forekommer der interessante ændringer i betydningen af især human kapital. Særlig bemærkelsesværdigt er det, at en lang videregående uddannelse, som ellers er en af de sikreste indikatorer for at påbegynde frivilligt arbejde, viser sig ikke længere at have en signifikant indvirkning på at fortsætte i det frivillige arbejde. Dette resultat støttes af en lignende undersøgelse foretaget af Tang et al. (2010), om end resultatet ikke genfindes i Wilson \& Musick (1999).

Samtidig viser det sig meget overraskende, at beskæftigelse generelt lader til at have en negativ sammenhæng med stabilt frivilligt arbejde, om end det kun er for personer med en beskæftigelse med ufleksible arbejdstider, at den effekt er signifikant. Dette resultat indikerer, at fleksibel fri tid er langt vigtigere for at fortsætte i frivilligt arbejde end den humane kapital, der opbyg- 
Tabel 3.

Multivariat logistisk regressionsmodel for stabilt frivilligt engagement. $(n=755)$, (Pseudo-R $\left.{ }^{2}=0,08\right),(\alpha=10 \%)(* p<0,10 * * p<0,05 * * * p<0,01)$.

\begin{tabular}{|c|c|c|c|c|}
\hline & $\widehat{\beta}$ & $\mathrm{p}$ & se & $\mathrm{OR} \mid \mathrm{x}=1$ \\
\hline \multicolumn{5}{|l|}{ Kapitalressourcer } \\
\hline Fleksibelt lønarbejde (O-1) & $-0,38$ & 0,173 & 0,19 & 0,69 \\
\hline Ufleksibelt lønarbejde (o-1) & $-0,57^{* *}$ & 0,031 & 0,15 & 0,57 \\
\hline Studerende (0-1) & $-0,32$ & 0,555 & 0,39 & 0,73 \\
\hline \multicolumn{5}{|l|}{ Pensionist, arbejdsløs (ref.) } \\
\hline LVU (o-1) & 0,25 & 0,256 & 0,29 & 1,29 \\
\hline Helbred \& fysisk mobilitet (0-2) & $0,47^{* * *}$ & 0,004 & 0,26 & 1,61 \\
\hline Sociale netværk (o-4) & $0,26^{*}$ & 0,066 & 0,18 & 1,30 \\
\hline Tradition for frivillighed (o-3) & $0,22^{* * *}$ & 0,001 & 0,09 & 1,25 \\
\hline \multicolumn{5}{|l|}{ Livsfaser } \\
\hline $24-33(0-1)$ & 0,15 & 0,663 & 0,39 & 1,16 \\
\hline $34-43(0-1)$ & $0,59^{* *}$ & 0,016 & 0,45 & 1,81 \\
\hline \multicolumn{5}{|l|}{ 44-53 (ref.) } \\
\hline $54-63(0-1)$ & $0,46^{* *}$ & 0,049 & 0,38 & 1,59 \\
\hline $64-73(0-1)$ & 0,34 & 0,277 & 0,44 & 1,40 \\
\hline $74+(0-1)$ & 0,3 & 0,436 & 0,51 & 1,35 \\
\hline Børn i skolealder (o-1) & $0,4^{*}$ & 0,076 & 0,33 & 1,48 \\
\hline \multicolumn{5}{|l|}{ Organisatorisk kontekst } \\
\hline Religionsområdet (o-1) & $0,94^{* *}$ & 0,014 & 0,98 & 2,56 \\
\hline Medlemskab (o-1) & $0,51^{* *}$ & 0,011 & 0,34 & 1,67 \\
\hline Log årlige frivillige timer & $0,12^{* *}$ & 0,046 & 0,07 & 1,13 \\
\hline \multicolumn{5}{|l|}{ Kontrolvariable } \\
\hline Mand (o-1) & 0,18 & 0,249 & 0,19 & 1,20 \\
\hline Log år boet i lokalområde & $0,19^{* *}$ & 0,029 & 0,10 & 1,21 \\
\hline Konstant & $-2,99^{* * *}$ & 0,000 & 0,03 & 0,050 \\
\hline
\end{tabular}

ges gennem beskæftigelse. Det er således et modsatrettet resultat, i forhold til hvad man kan forvente ud fra kapitalteorien. Men det stemmer godt overens at frivilligt arbejde er en mindre nødvendig produktiv aktivitet, relativt til betalt arbejde. Skulle de to komme i karambolage, og er der ikke mulighed for at disponere frit over sin betalte arbejdstid, så opgives det ubetalte frivillige arbejde altså i højere grad (Wilson \& Musick 1999).

I studiet af tidsforbrug inden for frivilligt arbejde har det vist sig, at visse faktorer, der hænger sammen med hvorvidt man bliver frivillig, har en negativ indvirkning på hvor meget tid, man bruger på det frivillige arbejde (Qvist 
2014). ${ }^{10}$ Ligeledes finder studier som dette af stabilitet $i$ frivilligt arbejde, at mål, der forudsiger om man bliver frivillig, ikke nødvendigvis hænger sammen med eller ligefrem har en negativ sammenhæng med, om man fortsætter i det frivillige arbejde. I begge tilfælde er muligheden for selv at disponere over større mængder af fri tid et vigtigt omdrejningspunkt (McNamara \& Gonzales 2011).

Et enkelt human kapital-mål viser sig dog at have den forventede indvirkning: At være fysisk hindret på grund af handikap eller dårligt fysisk eller psykisk helbred har en signifikant negativ effekt på stabilt frivilligt arbejde. Det giver god mening, da handikap eller dårligt helbred er en helt konkret udfordring, når det kommer til at deltage i produktive aktiviteter såsom frivilligt arbejde. Spørgsmålet er desværre kun stillet i '12, men ved at se på lignende undersøgelser må det formodes, at der er tale om, at det er en forringelse af helbredet eller det fysiske mobilitetsniveau, som har ført til et ophør i det frivillige arbejde (Butrica et al. 2009; McNamara \& Gonzales 2011; Tang et al. 2010; Wilson \& Musick 1999).

Når fokus flyttes fra human kapital til de to andre kapitaltyper, så ses det overraskende nok, at graden af sociale netværk kun har en svag signifikant effekt - selv ved et mere lempeligt alfa-niveau på $10 \%$. Omfanget af sociale netværk antages sædvanligvis at øge sandsynligheden for at påbegynde frivilligt arbejde (Musick 2007; Wilson 2012), men lader altså ikke - ifølge studiet her - til at have en entydig effekt på at fortsætte i det frivillige arbejde. Inden for kulturel kapital ses der dog stadig en stærk forskel. For personer, der er vokset op med en stærk tradition for frivillighed i familien, er det næsten dobbelt så sandsynligt ${ }^{11}$, at de er stabilt frivilligt frem for personer, der ikke vokset op med en tradition for frivillighed overhovedet.

Inden for livsfaser ser vi kun en svagt signifikant positiv effekt af at have børn. Som forventet forekommer stabilitet i det frivillige arbejde i det voksne liv i 30erne og de tidlige 40ere samt midt i 50erne og ti år frem. For aldersgruppen i 30erne er det en effekt, der ikke udelukkende kan tilskrives beskæftigelse eller børn, som der er blevet kontrolleret for, men den har formentlig i højere grad at gøre med stabiliteten af disse forhold i voksenlivet. Lidt overraskende er det dog, at aldersgruppen 44-53 år viser sig at være den mindst stabile. Det er svært at komme med en fyldestgørende tolkning, men det er alderen, hvor de voksne børn flytter hjemmefra samt en af de aldersgrupper, hvor flest skilsmisser forekommer (Danmarks Statistik 2014). Følger man livsfaseteorien må man antage, at ustabilitet i hjemmet og i omgangskredsen kan have en negativ effekt på overskud til ikke-essentielle aktiviteter uden for hjemmet (Musick 2007).

Selvom kontrolvariablene ikke er det primære fokus for undersøgelsen, er det dog værd at nævne den signifikante effekt af antal år, som den enkelte har boet i sit lokalområde. At være relativt nytilkommet i et område kan dels antages at have medført, at det tidligere frivillige arbejde andetsteds er op- 
hørt, uden at et nyt nødvendigvis er påbegyndt (Butrica et al. 2009). Samtidig kan det forventes, at de mindre tætte bånd til lokalsamfundet gør det mindre sandsynligt, at individer kender til fortsatte muligheder for at engagere sig frivilligt lokalt (Granovetter 1973).

Også i den multivariate analyse viser alle mål for den organisatoriske kontekst sig fortsat at være signifikante. Det betyder, at disse organisatoriske forhold har en vigtig rolle at spille for stabilt frivilligt arbejde på trods af individuelle forskelle i livsfaser og kapitalressourcer. Dermed bekræftes altså forventningen om, at stabilitet i frivilligt arbejde ikke kan reduceres til et spørgsmål om ressourcer og livsfaser.

Det skal først nævnes, at den stærkeste organisatoriske effekt findes blandt frivillige inden for religionsområdet, som i gennemsnit har langt over dobbelt så høje odds $(\mathrm{OR}=2,56)$ for at være stabilt frivillige end personer, der er frivillige inden for andre arbejdsområder. Resultatet går igen hos (Wilson \& Musick 1999). Som påpeget i den teoretiske diskussion er religionsområdet dog et meget særligt område inden for den frivillige sektor. Samtidig er det et af de mindre frivillighedsområder i Danmark, hvor kun $15 \%$ af de frivillige befinder sig (Fridberg 2014). På baggrund af de to overvejelser, så har resultatet ikke den store betydning for sektoren som hele. Alligevel er fundet sociologisk interessant, fordi det peger mod, at den klassiske sociologiske forståelse af, at de mest traditionelt værdifunderede sociale fællesskaber samtidig er de mest bindende, også har gyldighed inden for den moderne frivillige sektor (Wilson \& Janoski 1995). Desuden viser det sig, at de religionsfrivillige både i højere grad er medlemmer og har en høj arbejdsintensitet, og derfor bliver det vigtigt at kontrollere for dette område i modellen.

Det er dog arbejdstimer og medlemskab, der er de mest alment interessante mål for den organisatoriske kontekst for den frivillige sektor som helhed. Blandt andet fordi disse går på tværs af arbejdsområder.

Her viser det sig, at antallet af timer, der er brugt på frivilligt arbejde inden for det sidste år i 2004, som forventet har en signifikant positiv sammenhæng med stabilt frivilligt arbejde. Det understreger, at det først og fremmest er de frivillige, der har investeret mindre mængder af tid i arbejdet for en frivillig organisation, der med størst sandsynlighed falder fra igen, og ikke de frivillige med det tidskrævende engagement, der brænder ud. Det resultat går igen i mange andre studier (Butrica et al. 2009; Choi \& Chou 2010; McNamara \& Gonzales 2011; Moreno-Jiménez \& Villodres 2010; Wilson \& Musick 1999).

Ser man på medlemskabet, så viser undersøgelsen, at når der kontrolleres for relevante individfaktorer samt andre organisatoriske forhold, så har medlemsfrivillige op mod dobbelt så stor sandsynlighed for at være stabilt frivillig end ikke-medlemsfrivillige $\left(\mathrm{OR}=1,67^{* *}\right)$. Det resultat er med til at sandsynliggøre den teoretiske formodning om, at de frivillige, der vælger at engagere sig som medlemmer, i højere grad bliver indlejret i ansvarsfulde beslutningsstrukturer og dermed forbliver i den enkelte forening og således i det frivillige 
arbejde som sådan. Den antagelse underbygges af andre empiriske studier, der især påpeger, at erfaringen af at have adgang til stærke og formaliserede indflydelsesmuligheder er stærkt positivt korreleret med intentioner om at fortsætte som frivillig (Allen \& Mueller 2013; Garner \& Garner 2011). I den danske frivillige sektor er både indflydelse og ansvar traditionelt blevet tilskyndet gennem en demokratisk funderet medlemskabsmodel inden for foreningen. De relativt nye former for ikke-medlemsbaserede frivillige - der for eksempel er organiseret af kommuner, selvejende institutioner, socialøkonomiske virksomheder eller store frivillige organisationer ${ }^{12}$ - er ikke automatisk garanteret muligheden for samme organisatoriske ansvar og indflydelsesmuligheder (Selle 1996), og det kan betyde, at disse frivillige ikke i samme grad fortsætter i det frivillige arbejde.

Sammenholder man betydningen af medlemskabet med arbejdsintensitet - som er to aspekter, der oftest følges positivt ad - så dannes der et klart billede af, at forpligtende og betydningsfulde roller inden for den enkelte frivillige organisation er helt essentielle for at knytte den enkelte til organisationen og dermed sikre en stabil frivillig indsats (Wollebæk \& Sivesind 2014).

Når det resultat er særligt interessant, så skyldes det for det første, at den mest markante udvikling i strukturen af det frivillige arbejde fra '04 til '12 er det skarpe fald i netop de medlemsfrivillige. Mens det i 2004 var $79 \%$ af de frivillige, der var medlemmer af den organisation, det frivillige arbejde blev udført for, er det tal nede på 70 \% i 2012 - altså et fald på 9 \%-point (Henriksen 2014a). For det andet, så er det gennemsnitlige tidsforbrug faldet fra 19 til 18 timer om måneden, og det kan indikere, at intensiteten af det frivillige arbejde ligeledes er svagt nedadgående ${ }^{13}$ (Henriksen 2014b). Begge disse danske udviklingstendenser falder godt i tråd med den internationale forskning, som peger på, at den frivilliges rolle i højere grad udvikler sig mod de mere uforpligtende former (Eliasoph 2011; Hustinx 2010b; Wollebæk \& Sivesind 2014). I relation til den udvikling - både internationalt og i Danmark - bidrager undersøgelsen her med et nyt kritisk perspektiv på det forhold, at en omstrukturering af den organisatoriske kontekst for frivilligt arbejde mod de ikke-medlemsbaserede og mindre arbejdsintensive indsatser i højere grad kan betyde en frivillig sektor, der har svært ved at holde på sine frivillige.

\section{Konklusion}

Selv kortvarig deltagelse i frivilligt arbejde er i høj grad et spørgsmål om livsfaser og ikke mindst kapitalressourcer. Men når foden først er inden for døren, betyder det mindre, hvor man er i livet og hvilke ressourcer, man har. De anvendte mål for human kapital såsom uddannelse og arbejdsmarkedsstatus, der samtidig udgør centrale mål for social stratificering, har ikke signifikant positiv betydning for stabilt frivilligt arbejde. Beskæftigelse med ufleksible arbejdstider viser sig ligefrem at have en negativ effekt. Desuden har sociale netværk kun en moderat betydning. Livsfaser har også i mindre grad den kla- 
re indvirkning, som vi finder i studier af påbegyndelsen af frivilligt arbejde. Anderledes ser det ud med målene for den organisatoriske kontekst. Både det at være medlem af den organisation, arbejdet udføres for, samt arbejdsintensiteten af det frivillige arbejde styrker omfanget af stabilt frivilligt arbejde. Det har desuden også en betydning, om arbejdet er religiøst baseret eller ej. For fremtidig forskning peger konklusionen her på, at studier af fastholdelse af frivillige i høj grad kan drage nytte af at se på flere forhold ved det frivillige arbejde og de frivillige organisationer frem for blot de frivillige selv. Derudover leder konklusionen frem til en bekymring for stabiliteten i det frivillige arbejde, når den holdes op imod de aktuelle organisatoriske udviklingstræk væk fra medlemskabet og hen imod en lavere arbejdsintensitet.

\section{Noter}

1. Den generelle afrapportering for undersøgelsen findes i Fridberg, Henriksen et al. 2014.

2. Blot $34 \%$ angiver at have skiftet til et nyt arbejdsområde mellem '04 og '12. Det betyder, at det kun er cirka en tredjedel af de stabile frivillige, der med sikkerhed har skiftet til en ny organisation.

3. Det snævre fokus på lang videregående uddannelse skyldes, at det har vist sig at være den eneste uddannelseskategori med en positiv indvirkning på den afhængige variabel.

4. Variablene er valgt med en målsætning om at undgå endogenitetsproblemer. Derfor er kategorien "venner og bekendte uden for nærmiljøet" samt "andre" udeladt, da disse kan tænkes netop at være personer man møder gennem det frivillige arbejde.

5. En tidligere model har indeholdt en opdeling af børn i skolealderen for både '04 og/eller '12 (Frederiksen \& Møberg 2014), men opdelingen gav ikke signifikante resultater og er derfor udeladt.

6. Det er dermed muligt, at en respondent kan være både medlem og ikke-medlem. Dette tager undersøgelsen her ikke højde for.

7. Under antagelsen om tilfældigt manglende besvarelser samt at det drejer sig om en relativ lille del af besvarelserne (5\%), mener jeg, at dette ellers udskældte metodiske greb kan forsvares i tilfældet her. Den umiddelbare effekt vil antageligvis være, at den estimerede betakoefficient for variablen vil være et lidt mere konservativt bud (Acock 2005).

8. Den eneste undtagelse er, at stabilt ikke-frivillige har boet længere tid i deres lokalområde end de frafaldne.

9. Disse sammenhænge er efterprøvet ved t-test i forskel $\mathrm{i}$ andele, men udeladt af tabellen af oversigtshensyn.

10. En tidligere version af denne model har forsøgt at inkorporere indsigterne fra studier af tidsforbrug i frivilligt arbejde ved at se på, om omfanget af arbejdstid samt ændringer i arbejdstid har en effekt på stabilitet. Det viste sig ikke at være tilfældet her.

11. $\mathrm{OR}=\mathrm{e}^{\left(0,22^{*}\right)}=1,93$

12. En tidligere version af modellen forsøgte at tage højde for, hvilke sektorer den frivillige var organiseret inden for - dvs. offentligt, foreningsliv, selvejende institutioner - men disse havde ingen klar effekt.

13. Eftersom der kun er tale om en mindre - men dog signifikant - ændring over to datapunkter i tid, bør der tages forbehold for, at dette fald kan være et mindre udsving og ikke udtryk for et fortsat fald i timetallet. 


\section{Litteratur}

Acock, A. C. 2005: "Working with Missing Values". Journal of Marriage and Family, 67(4):1012-28.

Allen, J. A., \& S. L. Mueller 2013: "The Revolving Door". Journal of Community Psychology, 41(2):139-55.

Butrica, B. A., R. W. Johnson, \& S. R. Zedlewski 2009: "Volunteer Dynamics of Older Americans". The Journals of Gerontology Series B: Psychological Sciences and Social Sciences, 64B(5):644-55.

Choi, N. G., \& R. J.-A. Chou 2010: "Time and Money Volunteering Among Older Adults: The Relationship Between Past and Current Volunteering and Correlates of Change and Stability". Ageing and Society, 30:1-23.

Coleman, J. 1988: "Social Capital in the Creation of Human Capital". American Journal of Sociology, 94:1-27.

Cuskelly, G. \& A. Boag 2001: "Organisational Commitment as a Predictor of Committee Member Turnover Among Volunteer Sport Administrators: Results of a TimeLagged Study". Sport Management Review, 4(1):65-86.

Danmarks Statistik 2014: Statistisk Årbog 2014. København: Danmarks Statistik.

Eliasoph, N. 2011: Making Volunteers. Princeton: Princeton University Press.

Elstub, S. 2010: "Chapter 9: Participation", i Rupert Taylor (red.): Third Sector Research. New York: Springer New York.

Flanagan, C. \& P. Levine 2010: "Civic Engagement and the Transition to Adulthood". The Future of Children, 20(1):159-79.

Frederiksen, M. \& R. J. Møberg 2014: "Alder, Kohorte og Livsfase i Frivilligt Arbejde", i Torben Fridberg \& Lars Skov Henriksen (red.): Udviklingen i Frivilligt Arbejde 2004-2012. København: SFI.

Fridberg, T. 2014: "Udviklingen i Frivilligt Arbejde 2004-2012", i Torben Fridberg \& Lars Skov Henriksen (red.): Udviklingen i Frivilligt Arbejde 2004-2012. København: SFI.

Fridberg, T.; L. S. Henriksen et al. 2014: Udviklingen i Frivilligt Arbejde 2004-2012. København: SFI.

Garner, J. T. \& L. T. Garner 2011: "Volunteering an Opinion: Organizational Voice and Volunteer Retention in Nonprofit Organizations". Nonprofit and Voluntary Sector Quarterly, 40(5):813-28.

Granovetter, M. S. 1973: "The Strength of Weak Ties". American Journal of Sociology, 78(6):1360-80.

Haski-Leventhal, D. \& D. Bargal 2008: "The Volunteer Stages and Transitions Model: Organizational Socialization of Volunteers". Human Relations, 61(1):67-102.

Henriksen, L. S. 2014a: "Ikke-konventionelle former for frivilligt engagement", i Torben Fridberg \& Lars Skov Henriksen (red.): Udviklingen i Frivilligt Arbejde 20042012. København: SFI.

Henriksen, L. S. 2014b: "Stabilitet og Dynamik - Perspektiver og skandinavisk udsyn", i Torben Fridberg \& Lars Skov Henriksen (red.): Udviklingen i Frivilligt Arbejde 2004-2012. København: SFI.

Hermansen, J. 2015: "The Impact of Nonresponse on Estimates of Volunteering in the Case of Denmark." Til bedømmelse ved tidsskrift.

Hustinx, L. 2010a: "I Quit, Therefore I Am? Volunteer Turnover and the Politics of SelfActualization". Nonprofit and Voluntary Sector Quarterly, 39(2):236-55.

Hustinx, L. 2010b: "Institutionally Individualized Volunteering: Towards a Late Modern Re-Construction". Journal of Civil Society, 6(2):165-79. 
Ibsen, B.; M. Thøgersen \& K. Levinsen 2013: Kontinuitet og Forandring i Foreningslivet. Odense: Syddansk Universitet.

Koch-Nielsen, E. \& K. Michaelsen 2003: Kommunal Frivillighed - Tre Casestudier. Odense: Center for frivilligt socialt arbejde.

McNamara, T. K. \& E. Gonzales 2011: "Volunteer Transitions Among Older Adults: the Role of Human, Social, and Cultural Capital in Later Life". The Journals of Gerontology Series B: Psychological Sciences and Social Sciences, 66B(4):490-501.

Meyer, J.; D. Stanley, L. Herscovich, \& L. Topolnytsky 2002: "Affective, Continuance, and Normative Commitment to the Organization". Journal of Vocational Behavior, 61:20-52.

Moreno-Jiménez, M. P. \& M. C. H. Villodres 2010: "Prediction of Burnout in Volunteers". Journal of Applied Social Psychology, 40(7):1-21.

Musick, M. 2007: Volunteers: a Social Profile. Bloomington: Indiana University Press.

Penner, L. A. 2002: "Dispositional and Organizational Influences on Sustained Volunteerism: an Interactionist Perspective". Journal of Social Issues, 58(3):447-67.

Qvist, H.-P. Y. 2015: "Deltagelse i Frivilligt Arbejde og Tidsforbrug på Frivilligt Arbejde: To Sider af Samme Sag?". Dansk Sociologi, 26(2):53-72.

Selle, P. 1996: "Norsk (Skandinavisk) Frivilligdom i Endring", i Elisabeth Toft Rasmussen \& Inger Koch-Nielsen (red.): Den tredje sektor under forandring. København: SFI.

Selle, P. 2013: "Reflektioner Kring Medlemsmodellens Betydelse", i Lars Trägårdh, Lars Skov Henriksen \& Hanna Hallin (red.): Civilsamhället klämt mellan stat och kapital. Stockholm: SNS Förlag.

Smith, D. H. 1994: "Determinants of Voluntary Association Participation and Volunteering: a Literature Review". Nonprofit and Voluntary Sector Quarterly, 23(3):243-63.

Svedberg, L.; J. von Essen \& M. Jegermalm 2010: Svenskarnas Engagemang Är Större Än Någonsin. Stockholm: Ersta Sköndal Högskola.

Tang, F.; N. Morrow-Howell \& E. Choi 2010: "Why Do Older Adult Volunteers Stop Volunteering?". Ageing and Society, 30(05):859-78.

Tang, F.; N. Morrow-Howell \& S. Hong 2009: "Institutional Facilitation in Sustained Volunteering Among Older Adult Volunteers". Social Work Research, 33(3):172-181.

Taniguchi, H. \& Thomas, L. D. 2010: "The Influences of Religious Attitudes on Volunteering". VOLUNTAS: International Journal of Voluntary and Nonprofit Organizations, 22(2):335-355.

Taylor, R. F. 2004: "Extending Conceptual Boundaries: Work, Voluntary Work and Employment". Work, Employment \& Society, 18(1):29-49.

Wilson, J. 2000: "Volunteering". Annual Review of Sociology, 26:215-40.

Wilson, J. 2012: "Volunteerism Research: a Review Essay". Nonprofit and Voluntary Sector Quarterly, 41(2):176-212.

Wilson, J. \& M. A. Musick. 1999: "Attachment to Volunteering". Sociological Forum 14(2):1-30.

Wilson, J. \& M. Musick 1997: "Who Cares? Toward an Integrated Theory of Volunteer Work". American Sociological Review, 62:1-21.

Wilson, J. \& T. Janoski 1995: "The Contribution of Religion to Volunteer Work". Sociology of Religion, 56(2):137-52.

Wollebæk, D. \& K. H. Sivesind 2014: Fra Folkebevegelse til Filantropi?. Oslo: Senter for forskning på sivilsamfunn og frivillig sektor.

Wuthnow, R. 1995: Learning to Care. New York: Oxford University Press. 